\title{
Comparison of Chelating Activity of Soy Sauce and Fish Sauce Produced in Asian Countries
}

\author{
Young Soon $\mathrm{LEE}^{*}$ and Seiichi HommA* \\ * Department of Nutrition and Food Science, Ochanomizu University, \\ Ohtsuka 2-1-1, Bunkyo-ku, Tokyo 112
}

\begin{abstract}
Sixteen soy sauces and 4 fish sauces produced in Asian countries were subjected to electrodialysis. Their nondialyzable fraction was determined for iron (II) chelating activity by HPLC using a gel permeation column equilibrated with $0.01 \mathrm{M}$ acetate buffer $(\mathrm{pH} 4)$ containing $0.1 \mathrm{mM}$ iron (II) sulfate. The Fe-complex of each sample was detected in melanoidin fractions and in uncolored fractions, and the characteristics of the sause sample were represented by the elution profiles of Fe-complex. The results show that the amount of iron chelated per $\mathrm{m} l$ of electrodialyzed soy sauce ranged from 0.11 to $1.95 \mathrm{mg}$, and that of the fish sauce ranged from 0.13 to $0.50 \mathrm{mg}$. The chelating activity of soy sauce was larger than that of fish sauce. The chelating activity of the sauces was not always correlated with the color intensity at $450 \mathrm{~nm}$ of the samples, since some iron complex appeared in uncolored fractions of HPLC analysis.
\end{abstract}

Soy sauce and fish sauce are typical seasoning materials consumed in the Asian countries, which also contribute to aroma and color formation in cooked foods. The fermentation process produces amino acids, peptides and reducing sugars, which are subsequently involved in the Maillard reaction to produce melanoidin. Browning reaction in food system is complicated, and the reaction rate is influenced by various conditions such as $\mathrm{pH}$, temperature, moisture, and metals.

In a preceding report ${ }^{11}$ melanoidin in soy sauce and fish sauce was characterized by molecular size and electrofocusing profiles. Increase in color intensity at $550 \mathrm{~nm}$ of soy sauce due to metal chelation was shown by HASHIBA $^{2)}$. HASHIBA et al. ${ }^{3)}$ also proved that oxidative browning of soy sauce was remarkably accelerated by the presence of iron. Since chelating activity may be one of the factors to characterize melanoidin in foods ${ }^{4) 5}$, the authors made a preliminary determination of iron (II) chelation by the HUMMEL and DREYER method $^{\text {()) }}$ using a gel permeation HPLC. The results $^{7)}$ showed that an excessive amount of sodium chloride caused formation of a peak and a trough of iron concentration profile in the effluent, resulting in the determination of the excessive amount of chelated iron. Desalting of sauce was found to be an essential step in the measurement of chelating activity of the sauce melanoidin by the HUMMEL and DREYER method. The authors ${ }^{7)}$ showed that the electrodialysis was effective for the separation of sodium chloride from melanoidin in the sauces.

In this study, the electrodialyzed soy sauce and fish sauce were determined for iron chelating activity by the HUMMEL and DREYER method $^{6)}$ using a gel permeation HPLC.

\section{Materials and Methods}

\section{Sample}

Sixteen samples of soy sauce and four samples of fish sauce were obtained from 8 countries, China, Japan, Korea, Philippines, Singapore, Taiwan, Thailand and Vietnam.

\section{Electrodialysis of sauce}

Five milliliters of each sample were subjected to electrodialysis with Micro Acylizer G-1100 (Asahi Kasei Chemicals Ltd., Japan) as report- 
ed in another study ${ }^{7)}$.

Measurement of iron chelated by sauce

The electrodialyzed sample was diluted with an equivolume of $\mathrm{pH} 4$ acetate buffer $(0.02 \mathrm{M})$ containing $0.2 \mathrm{mM}$ iron (II) sulfate, and was filtered through a Millex GS filter of $0.45 \mu \mathrm{m}$. The eluent was pH 4.0 acetate buffer $(0.01 \mathrm{M})$ containing $0.1 \mathrm{mM} \mathrm{FeSO}_{4}$. It was degassed by putting the bottle in a ultrasonic cleaner and then filtered through a membrance filter of $0.45 \mu \mathrm{m}$ before HPLC analysis.

The HPLC column of TSK G-3000 PW $(7.5 \times$ $600 \mathrm{~mm}$; Tosoh Ltd., Tokyo) connected with a precolumn of PWH $(7.5 \times 75 \mathrm{~mm}$; Tosoh Ltd., Tokyo) was equilibrated with $210 \mathrm{~m} l$ of the eluent. One hundred microliters of the sample was charged on the HPLC, and the elution was carried out at a flow rate of $1 \mathrm{ml} / \mathrm{min}$ being monitored by optical density at $450 \mathrm{~nm}$ with scale range of 0.01 to 2.5 AUFS. The eluate was collected in $4 \mathrm{ml}$ fractions. After each HPLC analysis the column was successively eluted with $60 \mathrm{~m} l$ of $0.05 \mathrm{M}$ EDTA, $60 \mathrm{~m} l$ of $0.005 \mathrm{~N} \mathrm{NaOH}$ and $240 \mathrm{~m} l$ of water at a flow rate of $1 \mathrm{ml} / \mathrm{min}$.

\section{Determination of iron}

The collected fractions were measured for their iron concentration by atomic absorption spectrophotometry (Shimazu AA-670) without ashing treatment. The standard iron solution (Wako Purechemical Industries Ltd.) was diluted with $0.01 \mathrm{~N}$ hydrochloric acid to give an iron concentration range of 1 to $10 \mathrm{ppm}$.

Determination of chelated iron

Amount of chelated iron was calculated by the quantity of iron corresponding to total peak area or trough area of the iron concentration profile of the HPLC.

\section{Results and Discussion}

\section{HPLC patterns of melanoidin and iron}

The elution profiles of the sauce melanoidin and the iron concentration in the effluent are shown in Fig. 1. The elution profiles of sauce melanoidin were more complex than the iron concentration profiles. The iron concentration profile showed 1 to 3 major peaks in Fr. 4-20 for all the samples and 1 to 2 troughs in $\mathrm{Fr}$.
18-23. An iron peak is indicative of the presence of $\mathrm{Fe}-$ complex in the fractions. $\mathrm{Al}-$ though a peak in the iron concentration profile existed in the melanoidin fractions of most samples, it was also formed in the uncolored fractions for some samples, in which $\mathrm{Fe}-$ complex was eluted more later than the factions corresponding to amino acid. It seems to be due to the adsorption of Fe-complex to the column. The samples such as Korea-soy-2, Singapore-soy-2, Taiwan-soy-2 and Thailandsoy-3 produced very small iron peaks or no peak at all, but only troughs. It is speculated that some complex of iron and sauce melanoidin was either adsorbed to the column or insoluble due to formation of macromolecules by chelation. It should be noted that precipitation occurred in some of these tested sauces immediately after the addition of iron (II). When the HPLC column was eluted with $60 \mathrm{~m} l$ of $0.05 \mathrm{M}$ EDTA after each HPLC performance, peaks detected by optical density at $450 \mathrm{~nm}$ appeared. Since they showed similar absorption spectra in UV and visible range, they were regarded as melanoidin adsorbed to the column. The iron concentration profile of this HPLC is characteristic of the sauces and may be utilized to categorize sauces.

Only one iron peak was found in the Philippines-soy-2, Taiwan-soy-1 and Thailand-soy-1 samples. Among them Taiwan-soy-1 showed the largest peak.

Two iron peaks were formed in the soy sauce and fish sauce samples of China-soy-1, 2, Korea-soy-3, Singapore-soy-1, Thailand-soy-2, China-fish, Thailand-fish-3 and Vietnam-fish. China-soy-1, 2, Korea-soy-3 and Thailandsoy-2 were found to have two peaks of a similar height; one was in the melanoidin fractions and other was in the uncolored Fr. 15-21 just before the trough. China-soy- 1 and -2 showed the largest peaks and troughs. One major peak for Singapore-soy-1 and Thailandfish-3 existed in the melanoidin fractions. Two peaks for China-fish and Vietnam-fish also existed in the melanoidin fractions.

Three peaks were found in Japan-soy-1, 2, Korea-soy-1, Philippine-soy-1 and Thailand- 

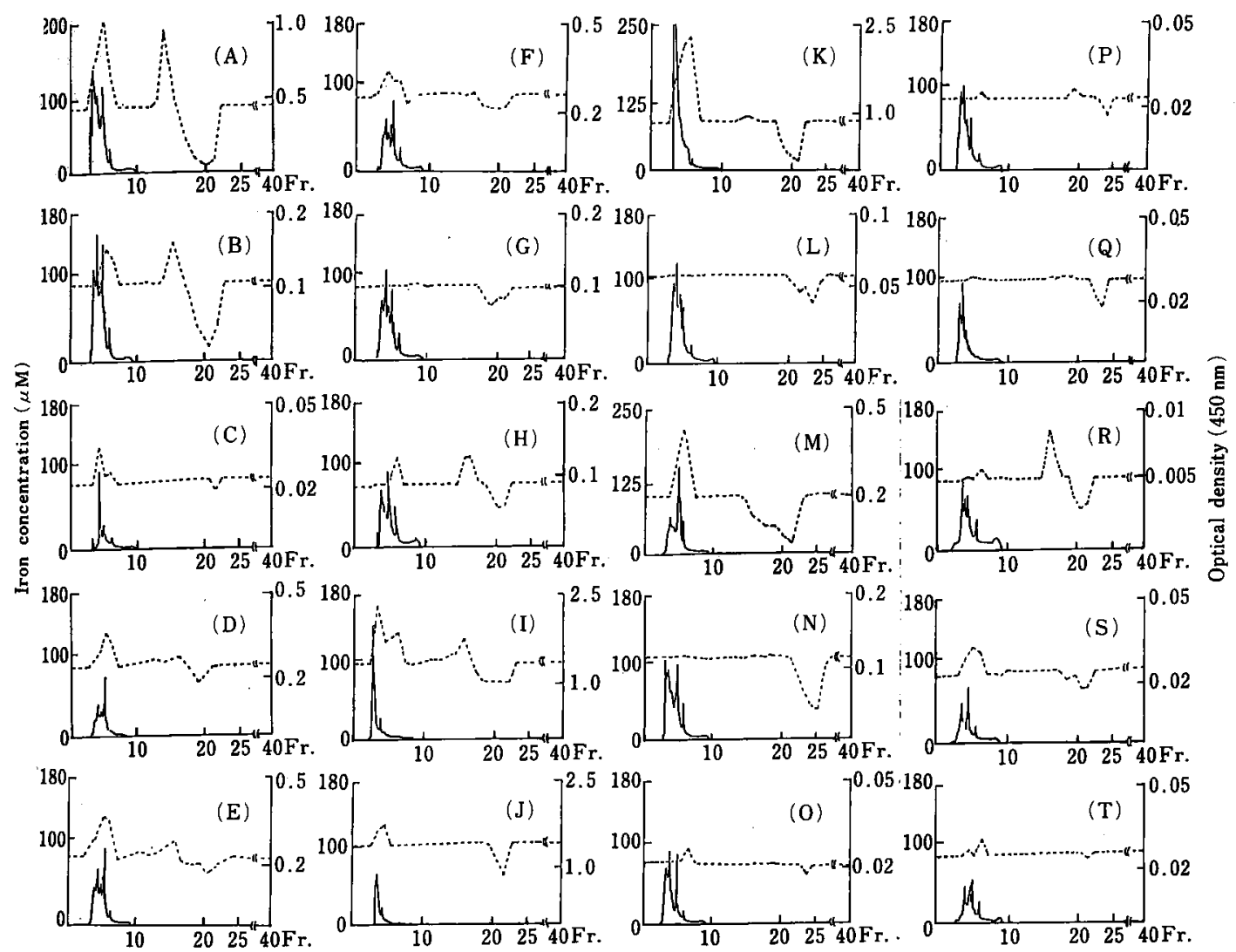

Fig. 1 HPLC of electrodialyzed soy sauce and fish sauce with the eluent containing iron (II) sulfate

Chromatographic conditions ;

Column : TSK G-3000 PW $(7.5 \times 600 \mathrm{~mm})$ connected with a precolumn of TSK PWH $(7.5 \times 75 \mathrm{~mm})$.

Eluent : $0.01 \mathrm{M}$ acetate buffer $(\mathrm{pH} 4) / 0.1 \mathrm{mM} \mathrm{FeSO}_{4}$.

Flow rate : $1 \mathrm{ml} / \mathrm{min}$.

Detection : optical density at $450 \mathrm{~nm}$ iron conc. $\mu \mathrm{M}$

Fraction : $4 \mathrm{ml}$.

Sample

(A) China-soy-1, (B) China-soy-2, (C) China-fish, (D) Japan-soy-1, (E) Japan-soy-

2, (F) Korea-soy-1, (G) Korea-soy-2, (H) Korea-soy-3, (I) Philippines-soy-1,

(J) Philippines-soy-2, (K) Singapore-soy-1, (L) Singapore-soy-2, (M) Taiwan-soy-1,

(N) Taiwan-soy-2, (O) Thailand-soy-1, (P) Thailand-soy-2, (Q) Thailand-soy-3,

(R) Thailand-fish-1, (S) Thailand-fish-3, (T) Vietnam-fish

fish-1, and among them one high peak was found in Japan-soy-2, Philippines-soy-1 and Thailand-fish-1.

Only one trough was found in the samples of China-soy-1, 2, Japan-soy-1, 2, Korea-soy-1,
3, Philippines-soy- 1,2 , Singapore-soy-1, Taiwan-soy-2 and Thailand-soy-1, 2, 3, Chinafish, Thailand-fish-1 and Vietnam-fish.

Two troughs were found in Korea-soy-2, Singapore-soy-2, Taiwan-soy-1 and Thailand- 
fish-3. A trough of fish sauce (China-fish, Thailand-fish-3 and Vietnam-fish) seems to be smaller than that of soy sauce in general. Some fish sauces are added with sugar and other saccharides for seasoning and caramel for colorization during processing, and these additives are involved in the amino-carbonyl reaction to form chelating compounds and finally melanoidin.

Amount of iron chelated

Amounts of iron corresponding to total peak areas and trough areas on the HPLC chromatogram were taken as the amount of iron chelated with the sauces, and chelating activity is shown as $\mathrm{mg}$ iron per $\mathrm{ml}$ of sauce (Table 1 ). According to the HuMmel and DREYer method amount of bound molecule was calculated based on a trough area. But, the amounts of iron chelated by the sauces should be a larger value of either peak or trough. Because it is due to the intrinsic iron $^{3) 53}$ bound to melanoidin and adsorption of $\mathrm{Fe}$-complex to the column that

Table 1 Iron chelating activity of electrodialyzed soy sauce and fish sauce

\begin{tabular}{|c|c|c|c|}
\hline \multirow{2}{*}{ Sample } & \multirow{2}{*}{$\begin{array}{l}\text { Color } \\
\text { intensity } \\
\text { at } 450 \mathrm{~nm}\end{array}$} & \multicolumn{2}{|c|}{ Iron chelating activity $(\mathrm{mg} / \mathrm{m} l)$} \\
\hline & & peak & trough \\
\hline \multicolumn{4}{|l|}{ China } \\
\hline soy-1 & 78.00 & 1.95 & 1.62 \\
\hline soy -2 & 23.04 & 0.86 & 1.18 \\
\hline fish & 3.59 & 0.29 & 0.07 \\
\hline \multicolumn{4}{|l|}{ Japan } \\
\hline soy -1 & 20.52 & 0.72 & 0.23 \\
\hline soy-2 & 30.60 & 0.85 & 0.30 \\
\hline \multicolumn{4}{|l|}{ Korea } \\
\hline soy-1 & 29.16 & 0.36 & 0.37 \\
\hline soy -2 & 16.68 & 0.07 & 0.35 \\
\hline soy -3 & 19.08 & 0.52 & 0.33 \\
\hline \multicolumn{4}{|l|}{ Philippines } \\
\hline soy-1 & 63.00 & 1.11 & 0.71 \\
\hline soy -2 & 68.48 & 0.17 & 0.34 \\
\hline \multicolumn{4}{|l|}{ Singapore } \\
\hline soy-1 & 162.00 & 1.82 & 0.97 \\
\hline soy -2 & 8.88 & 0.07 & 0.38 \\
\hline \multicolumn{4}{|l|}{ Taiwan } \\
\hline soy-1 & 30.60 & 0.96 & 1.80 \\
\hline soy -2 & 13.24 & 0.12 & 0.83 \\
\hline \multicolumn{4}{|l|}{ Thailand } \\
\hline soy-1 & 3.84 & 0.11 & 0.08 \\
\hline soy-2 & - & 0.11 & 0.12 \\
\hline soy-3 & 3.12 & 0.09 & 0.26 \\
\hline fish-1 (shrimp) & 0.79 & 0.50 & 0.45 \\
\hline fish-3 (pomfret) & 2.94 & 0.37 & 0.32 \\
\hline \multicolumn{4}{|l|}{ Vietnam } \\
\hline fish & 2.64 & 0.13 & 0.04 \\
\hline
\end{tabular}

Color intensity is shown by the value of optical density at $450 \mathrm{~nm}$ multiplied by dilution rate. 
the values for peak area and trough area are not always equal in this study. The amount of iron chelated by the electrodialyzed sauces was found to be from 0.11 to $1.95 \mathrm{mg}$ per $\mathrm{m} l$ of sample. As shown in Table 1, chelating activity of soy sauce is generally stronger than that of fish sauce. The sample of China-fish was found to chelate $0.29 \mathrm{mg}$ iron per $\mathrm{m} l$ and Vitnam-fish was 0.13 . Chelating activity of China-fish and Vietnam-fish was less than that of Thailand-fish-1 and -3 .

Chelating activity of the sauces tested was not always correlated with the color intensity of the sauces. It is also supported by the presence of $\mathrm{Fe}$-complex in the uncolored fractions. Since HASHIBA ${ }^{2)}$ isolated a strong chelating compound such as 2-hydroxymethyl3,5-dihydroxy-1-(4-pyridone)-acetic acid in browned materials prepared by the model system of Amadori compounds, the chelating activity of sauce depends on these low molecular compounds and macromolecules such as melanoidin and polysaccharide remaining after the fermentation. For the measurement of the chelating activity of sauce melanoidin, the separation and purification of melanoidin are essential, and the authors work on the utilization of a metal chelating column for characterization of melanoidin.

Acknowledgment. This study was supported in part by the Salt Science Research Foundation and a Grant-in-Aid for Scientific Research (01580060) from the Ministry of Education, Science and Culture of Japan.

\section{References}

1) Lee, Y.S., Homma, S. and Aida, K. : Nippon Shokuhin Kogyo Gakkaishi, 34, 313
(1987).

2) Hashiba, H.: Amino-carbonyl Reactions in Food and Biological System ed. by Fujimaki, M., Namiki, M. and Kato, H. (Kodansha-Elsevier, Tokyo) p. 155 (1986).

3) Hashiba, H., Koshiyama, I., Sakaguchi, K. and IGUCHI, N.: Nippon Nogeikagaku Kaishi 44, 312 (1970).

4) Asakura, T., Nakamura, Y., Inoue, N., Murata, M. and Homma, S.:Agric. Biol. Chem., 54, 855 (1990).

5) Gomyo, T. and Horikoshi, M.: Agric. Biol. Chem., 40, 33 (1976).

6) Hummel, J.P. and DreYer, W.J. : Biochim. Biophys. Acta, 63, 530 (1962).

7) LeE, Y.S. and Homma, S. :Nippon Shokuhin Kogyo Gakkaishi: 38, 556 (1991).

(Received Jun. 8, 1990)

\section{アジア諸国の款罯と魚罯のキレート能の比較 \\ 李 榮淳" ・ 本間清一” \\ *扔茶の水女子大学 家政学部 食物学科 \\ （テ112 東京都文京区大塚 2-1-1）}

アジア諸国の款濖 16 種と魚酱 4 種を電気透析にかけ， 非透析性画分の $\mathrm{Fe}$ (II) キレート能を測定した. 方法 は $0.1 \mathrm{mM}$ 硫酸鉄（II）を含む $\mathrm{pH} 4$ 酢酸緩衙液に上 るゲル沪過クロマトグラフィー（GPC）に加，溶出 画分の鉄濃度を測定した。

その結果，鉄錯体はメラノイジン画分と非着色画分に 検出された。酱油の $\mathrm{Fe}$ (II) キレート能は，穀㺕は $0.11 \sim 1.95 \mathrm{mg} / \mathrm{ml} l$, 魚期は $0.13 \sim 0.50 \mathrm{mg} / \mathrm{m} l$ であ り，穀酱は一般に魚酱よりキレート能が大きい，穀畒の キレート能が酱油の色素濃度 (450 nm における吸光度) と相関しなかったことは鉄錯体が非着色画分にあ検出さ れたことと関連があると推定した。 